Bobchynets Lyubov, $\mathrm{PhD}$ (Philological Sciences),

Kyiv National Linguistic University, 73, Velyka Vasylkivska str., Kyiv, 03150, Ukraine

ORCID: 0000-0002-8326-1948

Shafir Oksana,

Senior Lecturer,

Kyiv National University of Trade and Economics, 19, Kyoto str., Kyiv, 02156, Ukraine

ORCID: 0000-0002-9917-6844

\title{
SOCIO-CULTURAL AND PROFESSIONAL-PRACTICAL APPROACHES IN TEACHING COMMUNICATION IN FOREIGN LANGUAGES
}

The paper deals with socio-cultural and professional-practical approaches in teaching foreign languages. The importance of extra-linguistic knowledge is stated, including non-verbal communication. Socio-cultural approach makes prominent the knowledge of polite forms of communication and professional idioms. The emphasis is made on students' broad outlook, critical thinking and encouraging for scientific research and planning their own future professional activities. Reading biographies and autobiographies of famous specialists may be of motivational value. Professionalpractical approach in teaching is based on organizing students' discussions and round tables with specialists and experts, which will enable the students to better understand professional activities. Making presentations with the following analysis, discussion and recommendations are also effective methods of developing communication skills.

Key words: teaching foreign communication, interactive methods of studies, non-verbal communication, round table, discussion

Бобчинець Любов, Шафір Оксана. Соціокультурний $і$ професійнопрактичний підходи у викладанні спілкування іноземними мовами.

Статтю присвячено соиіокультурному і професійно-практичному підходам у викладанні іноземних мов. Визначено важливість екстралінгвістичних знань, включаючи невербальну комунікачію. Сочіокультурний підхід пов'язаний зі знанням ввічливих форм спілкування та фразеологізмів з фаху. Значну увагу приділено широкому кругозору та критичному мисленню студентів, заохоченню до наукових пошуків $і$ планування майбутньої професійної діяльності. Читання біографій та автобіографій відомих фахівиів має мотиваційний потенціал. Професійно-практичний підхід у викладанні оснований на організаиії дискусій 
і круглих столів між студентами та спеціалістами, експертами, що дозволяє глибшому розумінню майбутньої професійної діяльності. Підготовка студентами презентаиій, їх аналіз, дискусії та рекомендаиії є також ефективними методами розвитку комунікативних вмінь.

Ключові слова: навчання іншомовного спілкування, інтерактивні методи навчання, невербальна комунікащія, круглий стіл, дискусія

Relevance of research topic. Successful communication in the world of globalization is of primary importance in business, economy, law, social life and personal interaction. To improve soft skills in professional communication is one of the main aims of modern education. Globalized world requires communication at all levels of life, active collaboration between different countries. Teaching English or other foreign languages should be based not only on supplying students with the necessary knowledge of grammar and vocabulary but also developing communication skills, critical thinking and creative approach in professional activities. The aim of our research is to suggest and describe teaching approaches and methods of improving students' communication skills in professional sphere.

Formulation of the problem. Recent researches in teaching foreign languages devoted to communicational skills are attempts of description of what communicative skills mean, but in our opinion each scientist analyzes only teaching communication skills on a basis of a particular specialization: teaching communicative skills to students of tax services (Sukalenko, 2015), economics (Kuznetsova, Miakisheva, 2014), medicine (Miskhodzheyeva, 2018), tourism (Panagiotidou, 2015), etc. We consider that global vision and general approaches should be elaborated to deal with communication skills in teaching foreign languages to students of different specializations. We suggest concentrating on socio-cultural and professional-practical approaches in teaching languages.

Socio-cultural approach in teaching foreign languages is based on a special attention to cultural aspects of communication: non-verbal communication, polite formulas, idioms and set expressions. S. Martinelli defines such external characteristics of culture as values and aesthetics (Martinelli, 2000, p. 16). Cultural values are revealed in language and speech.

Today, a modern educational institution requires introducing new approaches to learning that ensure the development of communicative, creative, professional competences and stimulate the need of the future specialist in self-education which is based on the content and organization of the educational process. The main aim of foreign language teaching in educational institutions is to develop vocational competences for the learners by improving all types of speech activity: reading, speaking, writing and listening.

Analysis of recent researches and publications. Communicative skills depend on personal communicative culture. Communicative culture comprises a system of 
knowledge, values and behavior patterns accepted in society and the ability to naturally realize them in business and emotional communication (Vynoslavska, 2005, p. 68). Developing communication skills means enriching cultural and social knowledge about the countries of the language of studies. Another important component of teaching a foreign language is non-verbal communication which is culturally specific.

L. Volkova emphasizes the importance of sociolinguistic competencies which include knowledge of national language etiquette, non-verbal behavior and the ability to communicate according to the social norms of behavior and social status of the interlocutors (Volkova, 2015, p. 18). Thus, the same sign may have different meaning depending on the language. There exists general non-verbal or body language signs characteristic of many cultures. At the same time there are specific body movements and gestures proper of some cultures. To avoid misunderstanding or conflicts in professional communication the students should have knowledge of non-verbal characteristics of the native speakers of the language they are studying. The components of non-verbal communication include mimics (facial expression), gestures (movements of different parts of the body) and proxemics (the distance between interlocutors). Eye contact, vivid movements of hands, shorter or longer distance between the speakers may depend on the cultural peculiarities.

The exercises of speaking practice should include the information about nonverbal communication as well as polite forms of verbal communication proper of the business partner's culture. Successful communication is based on understanding culturally-based behavior. Thus linguistic knowledge is not considered to be enough to speak well. Extra-linguistic knowledge is a significant part of communicational skills. There is no doubt that the knowledge of special vocabulary is a must. Many textbooks are full of vocabulary and grammar exercises and this reflects formal way of teaching foreign languages. Additional attention should be paid to culturally-based peculiarities of interaction and non-verbal characteristics of speech if we consider oral communication. For example, the distance between the speakers may be different depending on the national perception of space, thus in Ukraine the space between the speakers is $90 \mathrm{~cm}$, whereas in the United States it may reach up to $120 \mathrm{~cm}$. Students should be aware that written communication includes polite forms of speech proper of the language and depending on the culture.

Teaching special terms and professional vocabulary could be more effective if included in role play games and discussions according to the models of real situations of professional communication. Set expressions and professional idioms are important source of cultural information. Idioms will enrich the students' vocabulary and are easy to memorize due to vivid image they represent. Analyzing foreign idioms of professional origin (cash cow, software bug, tiger team) and comparing them with the idioms in native language will enable students to understand the cultural differences in the perception of the same concepts. Reading texts in professional field may 
significantly enrich students' vocabulary. As T. Sukalenko states, reading special professional texts develops students' critical thinking, the ability to analyze information and make their own conclusions about future professional activities (Sukalenko, 2015, p. 264).

Presenting main material. Nowadays is not enough being a good specialist in a particular field of activities. Soft skills or skills of effective interaction are one of the main targets of globalized world. To be an interesting interlocutor with a broad outlook and knowledge of the culture of the potential business partners will contribute to the development of long-term professional contacts and can be of great help in creating stable business relations.

Interdisciplinary approach in teaching foreign languages is one of the main tasks of modern educational programs, which could be successfully solved by introducing methods of teaching, motivating the students to make their own project works in foreign languages, making presentations, conducting discussions, reading literature in the original on the topics which could be of great help in creating their own companies in future, for example, reading interviews, autobiographies of famous economists, lawyers or businessmen or businesswomen (Henry Ford, Coco Chanel, Bill Gates, etc.). During presentations students will have a good opportunity to practise their communication skills in public: eye contact, open body position, smiles, making brief and specific speech. The ability to ask and answer questions also serves as an effective exercise during presentations. Every presentation should be analyzed and discussed in group on the possible way of its improvement. Teachers are not recommended to interrupt the presenters correcting their mistakes. All the corrections and advice should be made after the presentation. Giving presentations students train to be persuasive and positively perceived by the interlocutors. Communication skills include the ability of being good listeners, self-confident and polite speakers which can be developed in tasks of presentations and group discussions.

One of the obstacles to successful mastering a foreign language in educational institution is language learners' low motivation. That is why interactive technologies are of particular interest, the purpose of which is to create comfortable learning conditions for everyone to feel intellectual capacity. The basis of such educational process is cooperation and productive communication, aimed at team problem solving, developing the ability to allocate the main thing, set up goals, plan activities, distribute responsibilities, think critically, achieve significant results. Therefore, it is necessary to intensify the learning process using the appropriate interactive technologies.

The essence of interactive learning in educational process means the implementation of active group teaching methods to solve didactic problems. The teacher thus performs the functions of assistant in the work, consultant, organizer, becomes one of the sources of information. However, the teacher acts as equal actor in the educational process. Interaction excludes the dominance of any participant, opinion, point of view over others and must take into account specific experience and 
practical application. During such dialogues students learn to think critically, solve complex problems by analyzing circumstances and relevant information, considering alternative thoughts and making informed decisions, engaging in discussions, communicating with others.

The organization of the multilateral communication process is facilitated by the use of appropriate interactive teaching methods, which are aimed at the development of creative abilities, focus on activities that stimulate ingenuity. These include the following: brainstorming, project method, role-playing and business games, discussions, debates, round tables. Thus, the use of role-playing games, in which the learners communicate in pairs or in groups, allows not only to make the classes more diverse, but also gives the opportunity to demonstrate speech autonomy, to realize communication skills. They can help each other successfully to adjust their interlocutors' statements, even if the teacher does not give such a task. In project work students are involved in the search engine-created educational activity organized by the teacher. The use of project technologies makes it possible to form and develop research, communication, technological, information competencies, generates creativity, stimulates intellectual activity, develops communication skills, helps to form inter-subject links, teaches using information and telecommunication technologies in learning teamwork skills, develops social mobility.

In addition, all this increases the motivation of learners, since in this case language learning is not a goal, but a means of creating the end product of the activity. Even the weakest ones can prove themselves here to the fullest extent possible by fulfilling their mission, and as a result, every student contributes to the creation of the project.

Thus, the modern teaching of foreign languages involves the use of different approaches, the development of exercises that would contribute not only to the development of communicative skills in a foreign language, but to thinking, tolerance, polite communication, creative approach to solving students' professional problems, as well as scientific and professional search.

A multi-disciplinary approach in teaching foreign languages will allow teachers to apply knowledge of special subjects in foreign classes, to work out situations of professional communication, facilitates the communicative training of future specialists (Dudley-Evans, St John, 1998, p. 64).

In order to motivate students to study a foreign language (particularly English), a pedagogical experiment was conducted at Kyiv National University of Trade and Economics. While studying the topic «Financial centres» which contains professional terminology (including such notions as stock market, foreign exchange market, commodity market, securities market, bond market, bull market, bear market), firstyear students were suggested a comparative study of European market and securities market in Ukraine and the students had to compare their research with the expert opinions of specialists. For this purpose contacts with the elite international law 
company «Dentons» were established, and its experts were invited to hold a round table with students to discuss the research topic. The round table was held in the conference hall of the company, the leading lawyer Oleg Batyuk made a presentation, in which he described the work of the company, its main strategies and goals. The students were able to get acquainted with the requirements to the work of an international lawyer at the beginning of the round table and ask questions to the employees of the company. As a result of the creative discussion, the students and the specialists of the company came to a common conclusion that the securities market in Ukraine is not developed yet. «Dentons» partner and leading lawyer Volodymyr Monastyrsky stressed that today's students should contribute in future to the development of securities market in Ukraine and provide legal support to foreign investors in the state's economy.

Thus, in this experiment, English became a means of research and acquisition of new language competences. The round table with the use of different speech modes, helped to overcome the language barrier, familiarize with corporate language etiquette, develop communication skills, make a rapid acquisition of in-depth information and expand outlook. Thus, the introduction of non-standard and innovative forms of teaching in the educational process encourages students to develop communication skills, motivates to learn new information and use it in practice, encourages research in the professional field, and helps to use professional terminology during conversations. Such non-standard and innovative forms of teaching should be used by teachers to encourage students to pursue creative and scientific work for their professional development. It is of great value in teaching when the students are involved in professional practical activities during the lessons (Melnyk, 2019, p. 63).

Before organizing a round table, the following preparations should be made: choosing the topic and the aims of the round table, deciding the experts, consulting the participants of the round table, discussing of the problem, making conclusions about the ways of solving the discussed problems (Interactyvni metody vykladanny, 2017, p. 52). The principle of equality and polite atmosphere should be followed during round tables and group discussions.

Conclusion. Teaching foreign languages for students of non-linguistic specialization should obligatorily include socio-cultural and professional-practical approaches. Socio-cultural approach is based on the knowledge of non-verbal characteristics of communication, idioms, polite forms of communication which are culturally specific and depend on religion and traditions of the society. Reading special journals, biographies and autobiographies of famous specialists in the original may represent an interesting and motivating task for students. Professional-practical approach suggests interdisciplinary forms and methods of teaching which comprise discussions and round tables in foreign languages organized among the students and also with specialists of the students' specialization: lawyers, economists, managers and others. During such discussions and round tables the students will be able to ask 
questions, to better understand practical aims and in future to plan their own professional activities. Preparing presentations with the following discussion and recommendations are also effective methods of improving communication skills. Teachers should also encourage students to take part in scientific conferences and conduct their own research on the topics the students are interested in, thus creating the atmosphere of constant search for improving communication skills and critical thinking.

\section{REFERENCES}

1. Dudley-Evans, T., St John, M. (1998). Developments in ESP: A multidisciplinary approach. Cambridge: Cambridge University Press, 301 p.

2. Interactyvni metody vykladannia. (2017). Praktychni porady dlia suddivvykladachiv. National School of Lawyers of Ukraine. Kyiv: FOP Demchynskyi O. V., $64 \mathrm{p}$.

3. Kuznetsova, N. E., Miakisheva. (2014). Pedagogicheskie osnovy prepodavaniya angliyskogo yazika studentam pervogo kursa ekonomicheskih spetsialnostey. Internetzhurnal «Naukovedenie». 1. Jan.-Febr. Retrieved from: http://naukovedenie.ru 72PVN114.

4. Martinelli, S., Taylor, M. (2000). Intercultural Learning. T-kit. Strasbourg: Counsil of Europeand European Comission, 106 p.

5. Melnyk, K. (2019). Formuvannia profesiynoyi kompetentnosti maibutnikh fakhivtsiv finansovoho profiliu v protsesi navchalno-vyrobnychoyi praktyky. Vyshcha Shkola., № 1, P. 57-64.

6. Miskhodzheyeva, F. A. (2018). Osobennosti prepodavaniya angliyskogo Yazika dlia meditsinskih tselei v visshei shkole. Vestnik Taukii obrazovaniya, № 10(46), C. 51-54.

7. Panagiotidou, P. (2015). English for Specific Purposes: How to Teach English for Tourism. International Journal of English Literature and Culture. Vol. 3(8). P. 235-238.

8. Sukalenko, T.M. (2015). Formuvannia komunikatyvnykh zdibnostei Maibutnikh fakhivtsiv fiskalnoi sluzhby. Naukovyi Visnyk Kafedry UNESCO KNLU. Seriia Filologiya Pedahohika. Psykholohiya,Is. 31, P. 261-267.

9. Volkova, L. V. (2015). Realizatsiya komunikatyvnoho pidkhodu u protsesi Vyvchennia inozemnoyi movy. Psykholoho-pedahohichniNauky, № 1, P. 17-22.

10. Vynoslavska, O. V. (2005). Psykholohiya: navchalnyi posibnyk. Kyiv : Inkos, P. 68-72. 